\title{
Faktor Ibu yang Berhubungan dengan Kejadian Persalinan Lama di RSUD Arifin Achmad Pekanbaru
}

\author{
Factors of The Mother Related to Obstructed Labour Case at RSUD Arifin \\ Achmad Pekanbaru
}

\author{
Yulrina Ardhiyanti, Susi Susanti
}

\section{Program Studi Kebidanan Sekolah Tinggi Ilmu Kesehatan Hang Tuah Pekanbaru}

\begin{abstract}
ABSTRAK
Persalinan lama merupakan salah satu penyebab kematian ibu dan janin. Pada ibu dapat menyebabkan terjadinya infeksi, kehabisan tenaga, dehidrasi, dan perdarahan post partum. Pada janin dapat menyebabkan terjadinya infeksi, cedera dan asfiksia. Persalinan lama dipengaruhi oleh faktor ibu, faktor janin, dan faktor jalan lahir. Tujuan penelitian adalah untuk mengetahui faktor ibu yang berhubungan dengan kejadian persalinan lama. Penelitian dilakukan di RSUD Arifin Achmad pada tahun 2013. Penelitian ini merupakan penelitian kuantitatif dengan desain penelitian case control. Jumlah sampel sebanyak 24 orang ibu yang mengalami persalinan lama sebagai kasus dan 24 orang ibu yang bersalin normal sebagai kontrol. Prosedur pengambilan sampel untuk kasus dengan cara total populasi dan pengambilan sampel untuk kontrol menggunakan teknik Systematic Random Sampling. Pengambilan data menggunakan lembar ceklis dengan variabel dependen persalinan lama, yaitu : persalinan memanjang yang berlangsung $>18$ jam dimulai dari tanda-tanda persalinan yang tercantum dalam diagnosa pada file/status ibu, variabel independen meliputi : usia, paritas dan his. Analisis data dilakukan secara univariat dan bivariat dengan uji chi-square. Hasil penelitian diperoleh bahwa terdapat hubungan usia dengan kejadian persalinan lama (OR : 4,000; 95\% CI : 1,583-46,277), terdapat hubungan paritas dengan kejadian persalinan lama (OR : 3,400; 95\% CI : 1,027-11,257) dan terdapat hubungan his dengan kejadian persalinan lama (OR : 9,308; 95\% CI : 1,778-48,723). Sebaiknya RSUD Arifin Achmad sebagai fasilitas kesehatan terdepan dalam pelayanan kesehatan masyarakat diharapkan dapat meningkatkan pelayanan kesehatan khususnya dengan memberikan penanganan segera persalinan dengan komplikasi yang memerlukan tindakan segera sehingga dapat mengurangi Angka Kematian Ibu dan Angka Kematian Bayi.
\end{abstract}

Kata Kunci : Persalinan Lama, His, Paritas, Usia

\section{ABSTRACT}

Obstructed labour is one cause of the death mother and fetus. On the mother, it can cause an infection, exhaustion, dehydration and post partum hemorrhage. On the fetus, it can cause an infection, injured and asphyxia. Obstructed labour is influenced by maternal factors, fetal factors, and factors of the birth canal. The purpose of research was to determine the maternal factors associated with the incidence of obstructed labour. This research was conducted at RSUD Arifin Achmad in 2013. This research is a quantitative research with case control study design. The samples used in this study were 24 mothers who experience as obstructed labour and 24 mother with normal birth as control. The sampling procedure for this case done by total population and sampling as control using Systematic Random Sampling technique. Collecting data methods using a checklist sheet with the dependent variable of obstructed labour, as known as: prolonged labour which last $>18$ hours starting from the signs of labour that are listed in the diagnosis of file / status of the mother, the independent variables include age, parity and his. Data analysis was performed using univariate and bivariate with chi-square test. The result showed that there is a relationship between age with the incidence of obstructed labour (OR : 4,000; 95\% CI: 1,583-46,277), relationship between parity with the incidence of obstructed labour (OR : 3,400; 95\% CI : 1,027-11,257) and relationship between his with the incidence of obstructed labour (OR : 9,308; 95\% CI : 1,778-48,723). We recommend that RSUD Arifin Achmad as the leading healthcare facilities in public health services is expected to improve health services, especially with the immediate response of labour with complications that require immediate action in order to reduce Maternal Mortality Rate and Infant Mortality Rate.

Keywords : Obstructed Labour, His, Parity, Age

\footnotetext{
${ }^{1}$ Alamat Korespondensi : Yulrina Ardhiyanti, Email: rien.ardhi@yahoo.co.id
} 


\section{PENDAHULUAN}

Persalinan lama adalah persalinan yang berlangsung lebih dari 18 jam yang dimulai dari tandatanda persalinan. Persalinan lama merupakan salah satu penyebab kematian ibu dan janin. Persalinan lama dapat menyebabkan infeksi, kehabisan tenaga, dehidrasi, dan perdarahan post partum yang dapat menyebabkan kematian ibu. Pada janin akan terjadi infeksi, cedera dan asfiksia yang dapat meningkatkan kematian bayi (Kusumahati, 2010).

Persalinan lama masih merupakan salah satu masalah di Indonesia khususnya didaerah pedesaan, dikarenakan masih banyak pernikahan yang terjadi pada usia dini. Insiden persalinan lama menurut penelitian 2,8-4,9 persen. Persalinan lama masih banyak terjadi dan keadaan ini menyebabkan angka kesakitan dan Angka Kematian Ibu (AKI) serta Angka Kematian Bayi (AKB) masih tinggi dan harus diupayakan mencegah terjadinya persalinan lama tersebut (Dewi, 2011).

Faktor-faktor yang mempengaruhi lamanya persalinan meliputi faktor ibu, faktor janin, dan faktor jalan lahir. Faktor ibu meliputi usia, his dan paritas. Faktor janin meliputi sikap, letak, malposisi dan malpresentasi, janin besar, dan kelainan kongenital seperti hidrosefalus. Sedangkan faktor jalan lahir meliputi panggul sempit, tumor pada pelvis, kelainan pada serviks dan vagina (Prawirohardjo, 2006).

Faktor ibu sangat penting bagi tiap persalinan yaitu usia, jika usia ibu kurang dari 20 tahun maka semakin muda umur ibu maka fungsi reproduksi belum berkembang dengan sempurna sehingga kemungkinan untuk terjadinya komplikasi dalam persalinan akan lebih besar. Jika usia ibu lebih dari 35 tahun juga beresiko, karena semakin tua umur ibu maka akan terjadi kemunduran yang progesif dari endrometrium sehingga untuk mencukupi nutrisi janin diperlukan pertumbuhan plasenta yang lebih luas. Sedangkan usia ibu yang aman itu 20-35 tahun karena alat reproduksi sudah matang (Putri, 2012).

Paritas dikatakan berisiko bila paritas lebih dari 4 kali sedangkan paritas yang tidak beresiko jika paritas 2-3 kali. Sedangkan his dikatakan baik jika memiliki frekuensi kurang dari 2x10 menit dengan durasi lebih dari 40 detik, dan his kurang jika memiliki frekuensi kurang dari 2x10 menit dengan durasi kurang dari 40 detik (Sumira dkk, 2013).

RSUD Arifin Achmad merupakan rumah sakit rujukan yang mempunyai fasilitas memadai, juga sebagai rumah sakit pendidikan yang memiliki rekam medik yang lengkap. Berdasarkan hasil survei pendahuluan yang telah dilakukan di RSUD Arifin Achmad Pekanbaru diketahui kasus persalinan lama merupakan urutan ke 13 dari 15 penyakit terbesar di ruangan Camar I dan II. Kejadian persalinan lama dalam tiga tahun terakhir mengalami perubahan. Pada tahun 2011, kejadian persalinan lama 0 kasus dari 2067 jumlah persalinan (0\%). Pada tahun 2012, persalinan lama mengalami kenaikan sebanyak 32 kasus dari 2908 jumlah persalinan $(1,10 \%)$ dan pada tahun 2013 , persalinan lama mengalami penurunan kembali menjadi 24 kasus dari 3236 jumlah persalinan $(0,74 \%)$ (Rekam Medik RSUD Arifin Achmad Pekanbaru, 2014). Berdasarkan data tersebut, peneliti tertarik untuk mengadakan penelitian dengan judul "Faktor Ibu yang Berhubungan Dengan Kejadian Persalinan Lama di RSUD Arifin Achmad Pekanbaru". Penelitian ini bertujuan untuk mengetahui faktor ibu yang berhubungan dengan kejadian persalinan lama.

\section{METODE}

Jenis penelitian ini adalah Analitik Kuantitatif dengan desain penelitian Case Control yang dilaksanakan pada bulan April 2015 di RSUD Arifin Achmad Pekanbaru. Jumlah sampel dalam penelitian ini sebanyak 24 orang ibu yang mengalami persalinan lama sebagai kasus yang diambil dengan cara total populasi dan 24 orang ibu yang bersalin normal sebagai control yang diambil dengan menggunakan teknik Systematic Random Sampling. Jenis data yang dikumpulkan adalah data sekunder yang dilakukan dengan menggunakan lembar ceklis dengan variabel dependen persalinan lama, yaitu : persalinan memanjang yang berlangsung $>18$ jam dimulai dari tanda-tanda persalinan yang tercantum dalam diagnosa pada file/status ibu, variabel independen meliputi : usia, paritas dan his. Analisis data dilakukan secara univariat dan bivariat dengan uji chi-square.

\section{HASIL}

Karakteristik responden pada kelompok kasus dan kelompok kontrol berdasarkan pendidikan dan pekerjaan sebagai berikut :

\section{Tabel 1.}

Karakteristik Responden pada Kelompok Kasus Berdasarkan Pendidikan dan Pekerjaan

\begin{tabular}{cccc}
\hline No & Variabel dan Kategori & F & $\mathbf{( \% )}$ \\
\hline 1. & Pendidikan & & \\
& Rendah (Tidak Sekolah, SD, & 17 & 70,8 \\
& $\begin{array}{c}\text { SMP) } \\
\text { Tinggi (SMA, Perguruan } \\
\text { Tinggi) }\end{array}$ & 7 & 29,2 \\
& Jumlah & 24 & 100 \\
\hline 2. & Pekerjaan & & \\
& Tidak bekerja & 21 & 87,5 \\
& Bekerja & 3 & 12,5 \\
\hline & Jumlah & 24 & 100 \\
\hline
\end{tabular}

Berdasarkan tabel 1, karakteristik responden pada kelompok kasus mayoritas berpendidikan rendah sebanyak 70,8 persen dan tidak bekerja sebanyak 87,5 persen. 
Tabel 2.

Karakteristik Responden pada Kelompok Kontrol
Berdasarkan Pendidikan dan Pekerjaan

\begin{tabular}{|c|c|c|c|}
\hline No & Variabel dan Kategori & $\mathbf{F}$ & $(\%)$ \\
\hline \multirow{4}{*}{1.} & Pendidikan & & \\
\hline & $\begin{array}{l}\text { Rendah (Tidak Sekolah, SD, } \\
\text { SMP) }\end{array}$ & 14 & 58,3 \\
\hline & $\begin{array}{l}\text { Tinggi (SMA, Perguruan } \\
\text { Tinggi) }\end{array}$ & 10 & 41,7 \\
\hline & Jumlah & 24 & 100 \\
\hline & Pekerjaan & & \\
\hline & Tidak bekerja & 16 & 66,7 \\
\hline & Bekerja & 8 & 33,3 \\
\hline & Jumlah & 24 & 100 \\
\hline
\end{tabular}

Berdasarkan tabel 2, karakteristik responden pada kelompok kontrol mayoritas berpendidikan rendah sebanyak 58,3 persen dan tidak bekerja sebanyak 66,7 persen.

Hasil analisis univariat didapatkan bahwa usia ibu yang berisiko (usia $<20$ dan $>35$ tahun) pada kelompok kasus sebanyak 15 orang $(31,3 \%)$ dan pada kelompok kontrol sebanyak 5 orang $(10,4 \%)$. Paritas yang berisiko (paritas >3) pada kelompok kasus sebanyak 17 orang $(35,4 \%)$ dan pada kelompok kontrol sebanyak 10 orang (20,8\%). Sedangkan his yang berisiko (his lemah) pada kelompok kasus sebanyak 11 orang $(22.9 \%)$ dan pada kelompok kontrol sebanyak 2 orang $(4,2 \%)$.

Hasil uji bivariat terhadap usia, paritas, dan his, semuanya mempunyai hubungan signifikan dengan kejadian persalinan lama yaitu faktor Usia (pvalue $=$ $0,000)$, faktor Paritas (pvalue $=0,042$ ) dan faktor His $(\mathrm{p} v a l u e=0,003)($ tabel 3).

Tabel 3

Faktor Ibu yang Berhubungan dengan Kejadian Persalinan Lama di RSUD Arifin Achmad Pekanbaru Tahun 2013

\begin{tabular}{|c|c|c|c|c|c|c|}
\hline \multirow[t]{3}{*}{ Variabel } & \multicolumn{4}{|c|}{ Persalinan Lama } & \multirow[t]{3}{*}{ p Value } & \multirow[t]{3}{*}{ OR (95\% CI) } \\
\hline & \multicolumn{2}{|c|}{ Kasus } & \multicolumn{2}{|c|}{ Kontrol } & & \\
\hline & n & $\%$ & $\mathbf{n}$ & $\%$ & & \\
\hline \multicolumn{7}{|l|}{ Usia } \\
\hline Berisiko $(<20$ dan $>35)$ & 15 & 31,3 & 5 & 10,4 & 0,000 & $4,000(1,583-46,277)$ \\
\hline Tidak berisiko (20-35) & 9 & 18,7 & 19 & 39,6 & & \\
\hline Total & 24 & 50 & 24 & 50 & & \\
\hline \multicolumn{7}{|l|}{ Paritas } \\
\hline Berisiko (>3) & 17 & 35,4 & 10 & 20,8 & 0,042 & $3,400(1,027-11,257)$ \\
\hline Tidak berisiko $(\leq 3)$ & 7 & 14,6 & 14 & 29,2 & & \\
\hline Total & 24 & 50 & 24 & 50 & & \\
\hline \multicolumn{7}{|l|}{ His } \\
\hline Berisiko (lemah : <20x10’, <40”) & 11 & 22,9 & 2 & 4,2 & 0,003 & $9,308(1,778-48,723)$ \\
\hline Tidak berisiko (kuat : $\left.>20 \times 10^{\prime},>40^{\prime \prime}\right)$ & 13 & 27,1 & 22 & 45,8 & & \\
\hline Total & 24 & 50 & 24 & 50 & & \\
\hline
\end{tabular}

\section{PEMBAHASAN}

Usia

Hasil penelitian ini menunjukkan bahwa 31,3 persen kelompok kasus dengan usia yang berisiko mengalami persalinan lama, sedangkan pada kelompok kontrol sebanyak 10,4 persen dengan usia yang berisiko mengalami persalinan lama. Hasil uji menunjukkan bahwa ada hubungan yang signifikan $(p<0,05)$ antara usia ibu dengan kejadian persalinan lama.

Menurut Wiknjosastro (2005), usia ibu merupakan salah satu faktor risiko yang berhubungan dengan kualitas kehamilan atau berkaitan dengan kesiapan ibu dalam reproduksi. Pada ibu dengan usia kurang dari 20 tahun, perkembangan alat-alat reproduksi belum matang sehingga sering timbul komplikasi persalinan, sedangkan pada ibu dengan usia lebih dari 35 tahun, mulai terjadi regresi sel-sel tubuh terutama endometrium sehingga menyebabkan proses kehamilan dan persalinan menjadi berisiko.

Penelitian ini sejalan dengan penelitian yang dilakukan oleh Mulyawati dkk (2011) dengan judul "Faktor Tindakan Persalinan Operasi Sectio Caesarea" yang menyatakan bahwa dari 60 responden, sebagin besar responden mengalami tindakan persalinan sectio caesarea yaitu dengan jumlah 47 responden $(78,3 \%)$. Sebagian besar responden berisiko yaitu $\leq 20$ tahun atau $\geq 35$ tahun yang berjumlah 40 responden $(66,7 \%)$. Hasil uji menunjukkan ada hubungan yang signifikan $(\mathrm{p}<0,05)$ antara usia ibu dengan persalinan operasi sectio caesarea.

Usia seseorang dapat mempengaruhi terjadinya persalinan lama karena umur ibu yang beresiko dalam kehamilan dan persalinan dapat mengakibatkan kurangnya kesiapan fisik dan psikologis bahkan komplikasi antenatal yang dapat mempengaruhi 
perkembangan dan pertumbuhan janin serta kesulitan dalam proses persalinan ibu.

\section{Paritas}

Hasil penelitian ini dapat dilihat bahwa 35,4 persen dengan paritas berisiko $(>3)$ mengalami persalinan lama, sedangkan pada kelompok kontrol sebanyak 20,8 persen dengan paritas berisiko mengalami persalinan lama. Hasil uji statistik menunjukkan bahwa ada hubungan yang signifikan $(\mathrm{p}<0,05)$ antara paritas dengan kejadian persalinan lama.

Menurut Wiknjosastro (2004),ibu yang sering melahirkan memiliki risiko mengalami komplikasi persalinan pada kehamilan berikutnya apabila tidak memperhatikan kebutuhan gizi. Pada paritas lebih dari tiga, keadaan rahim biasanya sudah lemah sehingga menimbulkan persalinan lama dan pendarahan saat kehamilan.

Penelitian ini sejalan dengan penelitian yang dilakukan oleh Mulyawati dkk (2011) yang menyatakan bahwa dari 60 responden, sebagian besar responden memiliki paritas $\geq 4$ mengalami tindakan persalinan sectio caesarea yaitu dengan jumlah 39 responden (65\%). Hasil uji menunjukkan ada hubungan yang signifikan $(\mathrm{p}<0,05)$ antara paritas dengan persalinan operasi sectio caesarea.

Paritas berisiko dapat menyebabkan terjadinya persalinan lama dikarenakan otot-otot rahim pada ibu yang sering melahirkan sudah melemah sehingga bisa mengakibatkan lamanya proses persalinan.

\section{His}

Berdasarkan hasil penelitian dapat dilihat bahwa sebanyak 22,9 persen dengan his lemah mengalami persalinan lama, sedangkan pada kelompok kontrol sebanyak 4,2 persen dengan his lemah mengalami persalinan lama. Hasil uji statistik menunjukkan bahwa ada hubungan yang signifikan $(p<0,05)$ antara his dengan kejadian persalinan lama.

Menurut Kuswanti (2013), his merupakan kontraksi otot-otot rahim dalam persalinan. Sifat his yang baik dan sempurna, yaitu : kontraksi yang simetris, fundus dominan (kekuatan paling tinggi berada di fundus uteri), kekuatannya seperti gerakan memeras rahim, setelah adanya kontraksi diikuti dengan adanya relaksasi dan pada setiap his menyebabkan terjadinya perubahan pada serviks, yaitu menipis dan membuka.

Penelitian ini sejalan dengan penelitian yang dilakukan oleh Sumarni dkk (2012) dengan judul "Faktor Determinan Lama Kala II Serta Dampaknya terhadap Pelepasan Plasenta pada Primigravida di RSKD Ibu dan Anak Siti Fatimah Makassar" yang menyatakan ada pengaruh frekuensi his terhadap lama kala II dengan nilai $p=0,046$ dan besar pengaruhnya 0,259 maka dapat disimpulkan bahwa ada pengaruh frekuensi his terhadap lama kala II. Pengaruh negatif yang diperoleh berarti semakin tinggi frekuensi his maka waktu yang dibutuhkan lama kala II semakin kurang.

Kuat dan lemahnya his pada saat proses persalinan sangat berpengaruh pada cepat atau lamanya suatu persalinan. Apabila pada saat proses persalinan his lemah, maka dapat memperlambat proses persalinan.

\section{KESIMPULAN}

Ditemukan hubungan yang signifikan $(\mathrm{p}<0,05)$ antara usia ibu, paritas dan his dengan kejadian persalinan lama. Ibu yang berusia $<20$ tahun atau $>35$ tahun lebih berisiko mengalami persalinan lama dibandingkan ibu yang berusia 20-35 tahun, ibu dengan paritas $>3$ lebih berisiko mengalami persalinan lama dibandingkan ibu dengan paritas $\leq 3$, dan ibu dengan his lemah pada saat persalinan lebih berisiko mengalami persalinan lama dibandingkan ibu dengan his kuat pada saat persalinan.

\section{SARAN}

Diharapkan RSUD Arifin Achmad sebagai fasilitas kesehatan terdepan dalam pelayanan kesehatan masyarakat dapat meningkatkan pelayanan kesehatan khususnya dengan memberikan penanganan segera persalinan dengan komplikasi yang memerlukan tindakan segera sehingga dapat mengurangi Angka Kematian Ibu dan Angka Kematian Bayi.

Selain itu, sebaiknya ibu lebih memperhatikan tentang kesehatannya untuk menghadapi kehamilan dan persalinan. Ibu sebaiknya memperhitungkan usia pada saat hamil dan membatasi jumlah anak serta memperhatikan gizi pada saat kehamilan. Sehingga nantinya bisa menghadapi kehamilan secara sehat dan proses persalinan dengan lancar.

\section{UCAPAN TERIMA KASIH}

Ucapan terima kasih ditujukan kepada Ketua STIKes dan Pimpinan serta staf RSUD Arifin Achmad Pekanbaru tempat penelitian ini dilakukan.

\section{DAFTAR PUSTAKA}

Kuswanti, Ina. (2013). Askeb II Persalinan. Yogyakarta : Pustaka Pelajar

Mato, Rusni. (2013). Jurnal Faktor-faktor yang Mempengaruhi Lamanya Persalinan pada Ibu Multipara. Makasar.

Mulyawati, I., Azam, M. \& Ningrum, D. (2011). Faktor Tindakan Persalinan Operasi Sectio Caesarea, (Online), Vol.7, No.1, (http://journal.unnes.ac.id/index.php/kesmas, diakses 10 Mei 2016) 
Notoatmodjo. (2010). MetodologiPenelitianKesehatan. Jakarta :Rineka Cipta.

Putri, Siska. (2012). Hubungan Umur dan Paritas dengan kejadian Perdarahan Post Partum di RSUD Arifin Achmad. Pekanbaru

Rekam Medik RSUD Arifin Achmad Pekanbaru Tahun 2013

Sumarah. (2009). Perawatan Ibu Bersalin. Yogyakarta : Fitramaya
Sumarni, Masni, \& Hadju, V. (2012). Faktor Determinan Lama Kala II Serta Dampaknya terhadap Pelepasan Plasenta pada Primigravida di RSKD Ibu dan Anak Siti Fatimah Makassar, (Online), (http://pasca.unhas.ac.id/jurnal/files/9eb5f57dc7 7cbb112632bf8d946b929f.pdf, diakses $10 \mathrm{Mei}$ 2016)

WHO. (2013). Pelayanan Kesehatan Ibu di Fasilitas Kesehatan Dasar dan Rujukan. Jakarta. 